\title{
EL PRINCIPIO DE LEGALIDAD PENAL EN LA HISTORIA CONSTITUCIONAL ESPAÑOLA
}

\author{
AGUSTÍN RUIZ ROBLEDO \\ Profesor Titular de Derecho Constitucional \\ Universidad de Granada
}




\section{SUMARIO}

I. Introducción. II. OJeada a los origenes del principio. III. El Derecho Penal en el Estado absoluto. IV. La Constitución de CÁdiz y la falta de una DECLARACIÓN EXPRESA SOBRE EL PRINCIPIO DE LEGALIDAD. V. LA CONSOLIDACIÓN DEL Estado liberal y los primeros Códigos Penales. VI. DE La Gloriosa a La II República. VII. El franquismo. VIII. Recapitulación. 


\title{
EL PRINCIPIO DE LEGALIDAD PENAL EN LA HISTORIA CONSTITUCIONAL ESPAÑOLA
}

POR

\author{
AGUSTIIN RUIZ ROBLEDO \\ Profesor Titular de Derecho Constitucional \\ Universidad de Granada
}

\section{INTRODUCCIÓN}

Como es de sobra conocido, una buena parte de la fructífera investigación histórica de Tomás y Valiente giró sobre el Derecho penal. Por eso, me ha parecido que la mejor forma de corresponder a la amable invitación del profesor TORRES DEL MORAL para colaborar en el homenaje a nuestro llorado ex-Presidente del Tribunal Constitucional, era remitirle este estudio histórico sobre el principio de legalidad penal, avanzadilla de un trabajo más amplio que preparo sobre dicho principio en la Constitución española. Se advertirá que me apoyo reiteradamente en la autoridad de TOMÁS Y VALIENTE para defender mis tesis. Quizás no sea superfluo señalar aquí que el trabajo - salvo las inevitables correcciones estilísticas- estaba terminado antes del aciago 14 de febrero, por lo que sus citas no están buscadas como un homenaje póstumo a su figura, sino como un sólido apoyo a una opinión tan modesta como la mía. Lo mismo es plenamente aplicable para la única ocasión en que me aparto, no sin temor, de su opinión. 


\section{OJEADA A LOS ORÍGENES DEL PRINCIPIO}

En el año 534 el Digesto de Justiniano (recogido de ULPIANO) establecía: "poena non irrogatur, nisi quae quoque lege vel quo alio iure specialiter huic delicto imposita est», no se establezca más pena que la impuesta especialmente por una ley u otro derecho para cada delito ${ }^{1}$. En 1215 la Magna Charta Libertatum del Rey Juan sin Tierra ordenaba en su artículo 29 que «nullus liber homo capiatur vel imprisonetur aut dissa siatur aut utlegatur aut exuletur aut aliquo modo destruatur nec super eum ibimus nec super eum mittemus nisi per legalem iudicium parium suorum vel per legem terrae»; ningún hombre libre será detenido, ni preso, ni privado de su propiedad, de sus libertades o libres usos, ni puesto fuera de la ley, ni desterrado, ni molestado de manera alguna, y Nos no pondremos ni haremos poner mano sobre él, a no ser en virtud de un juicio legal de sus pares y según la ley del país ${ }^{2}$.

Estos textos han dado lugar a una interesante polémica doctrinal. Así, para algunos el del Digesto es "la primera formulación legislativa" ${ }^{3}$ del principio de legalidad penal, mientras que para otros la Carta Magna le otorga a Inglaterra el honroso título de "patria del principio de legalidad» ${ }^{4}$. Si se quiere avivar la polémica se pueden añadir otros textos como los Fueros de Aragón de 1247 y la Charta Magna leonesa otorgada por don Alfonso, rey de León y Galicia, en las Cortes de León del año 1188, que «no sólo supera en antigüedad a la inglesa, sino en sentido democrático, como se diría en palabras de hoy" 5 .

Con ser importantes estas disposiciones, en cuanto manifiestan el deseo consciente de evitar el poder tiránico de los gobernantes, debemos precavernos de lo que PARETO denominó el prejuicio de los orígenes: la búsqueda obsesiva en el pasado de los embriones de las modernas catego-

1 Digesto, 50.16.131.1.

2 La Carta Magna puede consultarse en Jorge DE EsTEBAN (comp.), Constituciones españolas y extranjeras, 2.. ed., Taurus, Madrid, 1979, Vol II, pág. 108 y ss., de donde tomamos la traducción.

3 César Camargo Hernández, Introducción al estudio del Derecho penal, Bosch, Barcelona, 1964, pág. 126 y la extensa bibliografía allí citada.

4 Edmund Mezger, Tratado de Derecho penal, (trad. de J.A Rodriguez Muñoz), Revista de Derecho Privado, Madrid, 1955, Vol. I, pág. 132.

5 Luis JiMÉnEz DE AsÚA, Tratado de Derecho penal, 3. a ed., Losada, Buenos Aires, 1964, Tomo Il, pág. 386. 
rías. Por eso, nos parece muy acertada la opinión de JIMÉNEZ DE ASÚA que pone sordina a las voces que buscan en la noche de los tiempos el origen del principio de legalidad: "estos supuestos antecedentes, aunque tengan aparente parentesco con el problema que se estudia, responden a concepciones tan distintas y a vivencias tan diferentes que no podemos en verdad hallar en ellos el auténtico origen del problema que nos ocupa» 6 .

Algo parecido sucede en el plano teórico: se pueden rastrear los precedentes del principio de legalidad penal en BACON, como ha señalado LÓPEZ DE OÑATE ${ }^{7}$, HOBBES, como defienden SCHMITT Y BOBBIO ${ }^{8}$, en los teólogos renacentistas españoles, muy especialmente en ALFONSO DE CASTRO, como durante buena parte del siglo $X X$ ha querido un importante grupo de autores patrios ${ }^{9}$, y en tantos otros pensadores preocupados por la

6 Luis JiMÉNEZ dE AsúA, op. cit., Tomo IJ, pág. 383. Con carácter general, también se puede traer aquí a colación la opinión de Eduardo GARCIA DE ENTERRÍA sobre el cambio semántico de las palabras tras la Revolución francesa: «La lengua de los derechos debe explicarse, pues, no como una simple aparición de nuevos términos, en un plano estrictamente técnico de análisis léxico o sintáctico, sino como la expresión de un nuevo discurso jurídico que ofrece un nuevo modelo de relación entre los hombres" [ La lengua de los derechos. La formación del Derecho Publico europeo tras la Revolución Francesa, Alianza, Madrid, 1994, pág. 37].

7 Flavio López OÑATE, La certezza del diritto, Nuova edizione, in aggiunta saggi di Capograssi, Calamandrei, Carnelutti e Fedele, a cura di Guido Astuti, Appendice di M . Corsale, Giuffrè, Milán, 1968, (1. ed. en 1942), pág. 50, 67 y 124.

8 Ambos citados por Gonzalo Rodriguez Mourullo, "Legalidad (Principio de)", en Nueva Enciclopedia Jurídica, Tomo XIV, Seix, Barcelona, 1978, pág. 883. De la dificultad para leer el principio de legalidad en el Leviatán da idea de que mientras el creador de la teoría decisionista considera que Hobbes admite íntegramente la máxima nullum crimen, nulla poena sine lege, el iusfilósofo italiano piensa que sólo admite nullum crimen sine lege. A nuestro juicio, aunque es verdad que en el capitulo XXVII puede leerse que «ninguna ley que haya sido formulada después de que un hecho se ha cometido puede hacer de ese hecho delito", también es cierto que en el párrafo previo a esa idea Hobbes afirma tajantemente: «Si dicha pena ha sido ya determinada por la ley, el transgresor estará sujeto a ella; si no ha sido determinada, al transgresor se le castigará arbitrariamente". Es mas en el capítulo XVIII se encuentra otro párrafo en el que admite que la ley no tiene el monopolio punitivo: "Al soberano le corresponde el poder de premiar con riquezas $u$ honor, y de castigar con penas corporales o pecuniarias, o con ignominia, a todo súbito suyo, de acuerdo con la ley que haya sido previamente establecida; y si no se ha hecho ninguna ley actuará como le parezca más conveniente para dar a los hombres un incentivo que los haga servir al Estado, o para disuadirlos de que dañen al mismo" [Thomas HoBBEs, Leviatán (1651), trad. de Carlos Mellizo, Alianza, Madrid, 1989 , pág. 151, las citas anteriores en las págs. 237 y 236 , respectivamente].

9 Cfr. Eloy BULlón y FernándeZ, Alfonso de Castro y la ciencia penal, Madrid, 1900 y Marcelino Rodriguez Molinero, Origen español de la Ciencia del Derecho Penal. Alfonso de Castro y su sistema penal, Cisneros, Madrid, 1959, in totum y en especial págs. 6-23. En la actualidad más que de auténtico fundador del Derecho Penal moderno se prefiere calificar al autor de De potestate legis poenalis de precursor, tal y como argumentó Hinojosa a finales del XIX. RODRIGUEZ MOLINERO utiliza ampliamente la autoridad de Hinojosa para avalar su reivindicación de Alfonso de Castro, sin embargo silencia una de sus conclusiones fundamentales: «En resolución: la influencia de los teólogos 
arbitrariedad de los jueces (SANTO TOMÁS DE AQUINO, SUÁREZ, GROCIO, PUFFENDORF, etc). Sin embargo, lo cierto es que el principio de legalidad, tal como lo concebimos hoy, no tiene su origen hasta la llustración ${ }^{10}$, sólo entonces se le añade a la idea de que el juez debe estar sujeto a la ley, la idea de que esta ley no puede ser otra que la aprobada exclusivamente por un poder legislativo que represente a los ciudadanos. De épocas anteriores al "Siglo de las luces" no es difícil encontrar testimonios sobre la preocupación social por las penas desproporcionadas y la arbitrariedad judicial; pero, aunque forzáramos las categorías y cometiéramos el anacronismo de aplicarlas al Estado absoluto, sólo encontraríamos una vertiente del principio de legalidad, la seguridad jurídica, la necesidad de normas ciertas que excluyan la arbitrariedad de su aplicación ${ }^{11}$, pero no su ratio essendi, que no es otra que la división de poderes, el principio democrático ${ }^{12}$ para determinar lo que debe ser sancionado. Por decirlo parafraseando unos términos habituales de los especialistas del Derecho europeo: antes de la llustración había una honda preocupación por la fase descendente del principio de legalidad penal, pero no se planteó su fase ascendente.

españoles en el Derecho penal y procesal me parece haber consistido más bien que en introducir y acreditar instituciones nuevas, de los cual no podría encontrarse quizá ni un solo ejemplo, en haber contribuido a consolidar y arraigar las precedentes del Derecho romano y canónico, aclimatadas en nuestro suelo merced a la acción más directa y eficaz de los jurisconsultos, especialmente de los italianos comentadores de las fuentes del Derecho justinianeo" (Eduardo DE HINOJOSA, “influencia que tuvieron en el Derecho Público de su Patria y singularmente en el Derecho Penal los filósofos y teólogos españoles anteriores a nuestro siglo», (1889) en Obras, Vol. I, CSIC, Madrid, 1948, pág. 137).

$10 \mathrm{Cfr}$, por toda la doctrina mayoritaria de Derecho Penal, Gonzalo Rodríguez Mourullo, "Legalidad (Principio de)", cit., pág. 883. Para los historiadores del Derecho, cfr. Francisco Tomás $\gamma$ VALIENTE, El Derecho penal de la Monarquía Absoluta, 2." ed., Tecnos, Madrid, 1992, pág. 94 y ss. (en las páginas previas puede leerse una agudísima crítica a la tesis que considera a Alfonso de Castro el fundador del DP, en la pág. 92 se concluye que "Alfonso de Castro tampoco fue un penalista en el sentido actual del término, sino un filósofo del Derecho penal preocupado de servir a la Monarquía y a la religión dotando de un sólido soporte teológico a la ley penal y al ius puniendi realm).

11 Cfr. la impresionante recopilación de opiniones clásicas (comenzando por Aristóteles y Cicerón) que hace Flavio LóPEZ DE OÑATE, La certezza del diritto, cit., in totum y, en especial, pág. 45 y ss. Aunque en este libro nada se dice sobre la elaboración democrática de la ley, se trata de una obra que es "una esaltazione della legalita contro gli abusi dello stato totalitario, un importante strumento di quella resistenza che i giuristi di ispirazione democratica conducevano, in nome dei postulati del giusposi tivismo, contro l' arbitrio dei detentori del potere" (Massimo CORSALE ull problema della certezza del diritto in Italia dopo il 1950", en el "Appendice» a La certezza..., pág. 290).

12 Aunque no se nos escapa la diferencia que explicara Ortega entre el liberalismo, que sólo pretende limitar el poder, y la democracia que pretende participar en él, hacemos aquí sinónimo división de poderes y democracia en cuanto el principio de legalidad supone privar al Rey del ius puniendi y atribuirselo a una Asamblea, que por muy censitaria que sea, siempre expresa una voluntad más "democrática" que la voluntad unipersonal del Rey. En este sentido comparativo, y un tanto simplificador, emplearemos en las próximas páginas la expresión "democracia" y sus derivados. 
Como muestra de esos testimonios preilustrados, preocupados por la certeza del Derecho, pero no por su producción por un órgano democrático, nos permitimos traer a colación un texto que no hemos visto citado antes en la batalla de los precedentes y en el que se advierte con gran claridad lo que afirmamos: la petición 34 que hacen los procuradores de las Cortes castellanas de 1598. Así reza esta petición: «en las demás personas fuera de los nobles los jueces han tomado licencia de dalles tormento sin guardar la orden del Derecho, así en el sustanciar el pleito como en dalles traslado de los indicios, y también en atormentallos con nuevos géneros de tormentos exquisitos, y que por ser tan cruelles y extraordinarios que nunca jamás los imaginó la ley, de que se han seguido grandes inconvenientes, y que los reos forzados con la demasía y rigor de los tormentos y desesperados de sufrirlos, se hayan levantado testimonios a sí mismos, y culpado a otros falsamente; suplicamos a Vuestra Magestad se sirva de mandar que de aquí adelante, para dar tormento a cualquier persona, guarden los jueces puntualmente la forma del Derecho. Y que en en la calidad de los tormentos no los puedan dar por nuevas ni exquisitas maneras de tormento, sino en la forma que la ley lo tiene ordenado, pues mucho más justo es que el juez, rindiendo su entendimiento a la ley, yerre por ella, que no que procure acertar por su parecer, porque no puede haber buen gobierno en la república sino cuando el juez executa puntualmente lo que manda la leys ${ }^{13}$.

El principio de legalidad penal con sus dos vertientes, la de elaboración democrática y la de seguridad jurídica en su aplicación, sólo da sus primeros pasos dentro del Estado liberal porque es, en buena parte, un epifenómeno del principio de división de poderes ${ }^{14}$. Por eso, las primeras referencias modernas al principio de legalidad las hizo MONTESQUIEU en 1748, cuando publicó su imperecedero Del espíritu de las leyes. En él por primera vez se señala la directa, directísima, conexión que hay entre la libertad de los ciudadanos, la división de poderes y el principio de legalidad: «En los estados despóticos no hay leyes: el juez es su propia regla. En los Estados monárquicos hay una ley que el juez aplica en los casos en que es terminante; en los que no lo es, busca su espíritu. En el Gobierno republicano es propio de la naturaleza de la constitución que los jueces sigan la letra de

13 Actas de las Cortes de Castilla, XVI Cortes de 1592-1598, pág. 646, petición 34. Los subrayados son nuestros.

14 Pero, como muy bien advirtió Grasso (en contra de una opinión muy difundida) no es una condición sine qua non para lograr un Estado de Derecho ya que en el los países anglosajones $y$ en los escandinavos se ha obtenido éste sin tener áquel [Pietro GiussepPE Grasso, II principio «nullum crimen sine lege» nella costituzione italiana, Giuffrè, Milán, 1972, pág. 49]. 
la ley. No hay ciudadano contra el cual se pueda interpretar ninguna ley cuando se trata de sus bienes, de su honor o de su vida" ${ }^{15}$. Si recordamos que, para CHARLES-LOUIS DE SECONDAT, el gobierno republicano es aquel "en que el pueblo entero, o parte del pueblo tiene el poder soberano" y que en él "sólo el pueblo debe hacer las leyes", veremos que en la frase transcrita se encuentra los dos elementos esenciales del principio de legalidad: a) sólo el poder legislativo, representante del pueblo, puede determinar los delitos y las penas y b) los jueces deben aplicar estrictamente las leyes penales, excluyendo la analogía y las interpretaciones contra reo.

Pero el mérito principal de poner los cimientos del Derecho penal liberal $y$ de haber fijado expresamente el principio de legalidad se debe a CESARE BONESANA, Marqués de Beccaria, y a su famosísimo Dei delitti e delle pene publicado anónimamente en Livorno en 1764 y rápidamente difundido por toda la Europa culta ${ }^{16}$. En él, se fundamenta el ius puniendi del Estado en el contrato social y se argumenta en favor de que únicamente pueda ejercerse por el poder legislativo. El mejor resumen que puede hacerse de esta obra to hizo el mismo BECCARIA de manera excepcional, al terminar su libro de esta brillante forma: «De cuanto hasta aquí se ha dicho puede sacarse un teorema general muy útil, pero poco conforme al uso, legislador ordinario de las naciones, esto es: para que toda pena no sea violencia de uno o de muchos contra un particular ciudadano, debe esencialmente ser pública, pronta, necesaria, la más pequeña de las posibles en las circunstancias actuales, proporcionada a los delitos, dictada por las leyes" 17 .

Este teorema pasó a ser un objetivo fundamental de los partidarios de reformar el Antiguo Régimen; donde destacó con luz propia VOLTAIRE que

${ }^{15}$ De l'esprit des lois (trad. de Mercedes Blázquez y Pedro de Vega), Sarpe, Madrid, 1984, Libro VI, Cap. III, pág . 100. Otra ideas penales de Montesquieu son: la proporción de la pena con la gravedad del delito, la prohibición de la tortura, el daño como medida para establecer la pena, la despenalización de los «delitos contra la religión», etc. Cfr., el detenido estudio de Giovanni TARELLO, Storia della cultura giuridica moderna. Assolutismo e codificazione del diritto, II Mulino, Bolonia, 1993 (reedición, a en 1976), pág. 415 y ss.

${ }_{16}$ En España lo tradujo en 1774 Juan Antonio de las Casas, en una traducción tan correcta que todavía se sigue reeditando. Véase la cuidada edición de Juan Antonio DELVAL, con la inclusión del “Comentario al libro 'De los delitos y de las penas'» de VOLTAIRE, Alianza, Madrid, 1982 y un estudio de DELVAL sobre «Beccaria en España». También es muy conocida la impecable traducción de Franciso TOMÁS Y VALIENTE, Aguilar, Madrid, 1974, con introducción y notas del traductor (esta trad. está hecha sobre la 6. edición, que fue corregida por el propio Beccaria aceptando la nueva estructuración en 42 capítulos que hizo su traductor francés, mientras que la de Casas es de la $1 .^{\circledR}$ ed. y tiene 47 capítulos).

17 Op. cit. (trad. de Casas), pág. 112. Para la inmensa bibliografia sobre BECCARIA cfr. la selección que realiza TOMÁs Y VALIENTE en su «Introducción» cit. págs. 54-58. 
escribió un elogioso Commentaire sur le livre «Des délits et des peines». En España, lo hicieron suyo -normalmente orillando sus posturas más radicales- Lardizábal, Meléndez Valdés, Jovellanos, Cabarrús, Sempere y Guarinos, etc. ${ }^{18}$. Poco a poco en los ámbitos ílustrados españoles (como en la de sus correligionarios de otros países) se fue difundiendo la idea de que la lucha por el principio de legalidad era una lucha por el Estado de Derecho, el único capaz de garantizar los derechos individuales $\mathrm{y}$, desde luego, el único Estado con el que se podía lograr el gran objetivo jurídico de la burguesía: la seguridad jurídica, indispensable para el tráfico mercantil ${ }^{19}$. Por eso, el principio de legalidad se concebía no tanto como un instrumento de técnica jurídica neutral, sino como una herramienta política, de lucha contra el Antiguo Régimen; de ahí que se le considerase un postulado de rango constitucional. El principio de legalidad penal se encuentra en algunas Declaraciones de Derechos de los nuevos Estados americanos, como en la de Delawere de 1776 y en la Masachusettes de $1780^{20}$. Pero la fórmula canónica para la Europa continental es la Declaración de Derechos del Hombre y el Ciudadano de 1789, cuyo artículo 8 dispone: «La loi ne doit établir

18 Sobre la influencia de Beccaria en España vid., además de los trabajos de DelVAL y Tomás Y VALIENTE que acompañan a sus ediciones de De los delitos, José ANTÓN ONECA, «Los fines de la pena según los penalistas de la llustración", REPen, núm. 174, julio-septiembre de 1964, págs. 6 y ss.

19 Cfr. Domenico CorRaDinI, Garantismo estatualismo. Le codificazioni civilistiche del Ottocento, Giuffrè, Milán, 1984 (red 1. en 1971), según el cual “in lotta contro lo stato assoluto e contro il sistema pluralistico delle fonti ereditato dal medioevo e dal diritto romano valido come diritto comune, la borghesia, che ha messo profonde radici nel mondo economico, torna a reclamare con insistenza il valore della certeza legale e a scorgervi un requisito irrinunciabile per lo sviluppo dei trafficis (pág. 31). Cfr., también, Carlos de CABO MARTín, Teoría Histórica del Estado y del Derecho Constitucional, Vol. II, Estado y Derecho en la transición al capitalismo: el desarrollo constitucional; PPU, Barcelona, 1993, pág. 269 y ss.; en especial pág. 274 donde se afirma que en la nueva sociedad capitalista cel sujeto de derecho se configura como 'autónomo' que demanda una exigencia de certeza sobre el ámbito de esa autonomía, sus límites y procedimientos para desarrollarla". Ha resaltado la idea de "seguridad jurídica" del Estado liberal como una continuación, "no ya como hecho, sino como ideología", de la misma idea en el Estado absoluto Gregorio PECES-BARBA, Derecho y derechos fundamentales, CEC, Madrid, 1993, pág. 264 y ss.

20 El artículo 11 de la primera establecía «Que las leyes retroactivas que castigan delitos cometidos antes de la existencia de dichas leyes son opresivas e injustas y no deben dictarse". Por su parte, el artículo 24 de la Declaración de Derechos de Masachusettes decia: "Las leyes dictadas para castigar acciones realizadas con anterioridad a la existencia de dichas leyes y que no hayan sido declaradas delito por leyes precedentes, son injustas, opresivas e inconsistentes con los principios fundamentales de un gobierno libre" [Apud Miguel ARTOLA, Los derechos del hombre, Alianza, Madrid, 1986, págs. 57 y 58]. La Constitución federal de 1787 hace una declaración menos tajante: "No se aplicaran bill of attainderni leyes expost facto. Sobre la evolución del PL en EE.UU. (con interesantes referencias al Reino Unido) vid. Francisco Javier MELERo, «Codificación e interpretación judicial en el Derecho penal (introducción al estudio del Derecho sustantivo anglo-americano)", $A D P C P$, tomo XLVII, Fascículo II, mayo-agosto de 1994, pág. 88 y ss. 
que les peines strictement et évidemment nécessaires et nul ne peut etre puni q'en vertu d'une loi établie et promulgée antérieu rement au délit et légalement appliquée».

\section{EL DERECHO PENAL EN EL ESTADO ABSOLUTO}

Ya hemos visto diversos precedentes del principio de legalidad de nuestro Derecho Histórico como la Charta Magna leonesa, los Fueros de Aragón y la petición de los procuradores en las Cortes castellanas en 1598. Pero lo cierto es que el Derecho penal del Antiguo Régimen no estaba imbuido ni mucho menos por este principium. Y no sólo, evidentemente, en la faceta que hemos denominado política, de elaboración democrática de la lex, sino en su faceta puramente técnica: las definiciones de muchos delitos eran insuficientes, las penas se fijaban vagamente, la analogía estaba a la orden del día, etc, etc. Veamos, si no, como caracteriza TOMÁS Y VALIENTE el proceso penal castellano en su exhaustivo -e insuperado- trabajo sobre el Derecho penal de la Monarquía Absoluta ${ }^{21}$ :

1. Falta de imparcialidad del juez, debido a dos motivos: a) que casi siempre el juez que falla el proceso es el mismo que lo ha investigado; b) que tiene un interés personal en el resultado del proceso, porque participa en el reparto de las penas pecuniarias.

2. El sistema de pruebas se orienta contra el reo. En cuanto hay el más leve indicio opera el principio de culpabilidad. Así que en lugar de afirmarse que todo hombre es inocente mientras no se demuestre suficientemente su culpabilidad, la teoría de los indicios apunta hacia la presunta culpabilidad del sospechoso como reflejo jurídico del refrán «piensa mal y acertarás».

3. El reo se encuentra en una inferioridad procesal, no sólo por el secreto parcial de las actuaciones procesales como por la distinta valoración de las pruebas; así una confesión de culpabilidad bajo tortura será considerada una prueba decisiva, pero el torturado que negase su culpabilidad no por ello será absuelto.

21 El Derecho penal... cit., la primera edición es de 1969, aquí lo citamos por la 2." de 1992 (que es, en verdad, una reedición), pág. 199. 
4. Las garantías procesales probatorias de la culpabilidad se reducen para facilitar la persecución y el castigo de ciertos delitos.

5. El excesivo margen de arbitrio judicial que redundaba en: a) la consiguiente indeterminación de las penas, pues aun las que legalmente estuvieran bien determinadas, podían ser sustituidas por otras "arbitrarias", según la apreciación del juez; b) que las sentencias no fueran motivadas porque en la parte dispositiva de las sentencias falta su justificación y está siempre exenta de referencias al Derecho vigente; c) la incontrolada libertad de interpretación y de aplicación del Derecho, lo cual se traducía en la aplicación judicial de la doctrina o de la práctica curial local.

6. La confusa estructuración de las instituciones de administración de justicia penal; los órganos de las diversas jurisdicciones penales se entorpecían mutuamente y dificultaban no sólo la persecución de los delincuentes sino su efectiva y justa punición.

Como un ejemplo vale más que mil palabras, nos permitimos reproducir sucintamente aquí un caso que muestra la aplicación de la justicia en el Estado Absoluto y su completa ignorancia del principio de legalidad y sus garantías. La mayoría de los tratadistas suelen recoger alguno de los famosos casos franceses de Robert Damiens (que hirió a Luis XV en 1757), Jean Calas ${ }^{22}$ y del caballero de la Barre (ajusticiado en 1766 por no quitarse el sombrero a treinta pasos de una procesión). Pero nosotros, movidos por el mismo espíritu patriótico que nos ha hecho citar más arriba las demandas de justicia castellanas de 1598, nos hace preferir ahora un ejemplo hispano: la ejecución de Juan de Cañamas (loco, probablemente) en Barcelona en 1493 por haber atentado contra Fernando el Católico. Así lo cuenta ANDRÉS BERNÁLDEZ ${ }^{23}$ :

«El traidor fue condenado por la justicia de la ciudad a muy cruelísima muerte; fue puesto en un carro y traído por toda la ciudad, y primeramente le cortaron la mano con que le dió al Rey, y luego con tenazas de hierro ardiente le sacaron una teta, y después le sacaron un ojo, y después le cortaron la otra mano, y luego le sacaron el otro ojo, y luego la otra teta, y luego las narices, y todo el cuerpo y le abocadaron los herreros con tenazas ardiendo, e fuéronle

22 Como es sabido, la injusta condena a muerte en 1762 de este comerciante protestante, acusado de haber asesinado a su hijo, supuestamente convertido al catolicismo, fue el leit motiv del Traité sur la tolérance de VOLTAIRE. Cfr. Montserrat NEBRERA, «De la libertad ideológica poco antes de la Revolución francesa (su construcción desde la crítica a la intolerancia en Voltaire)", REP, núm. 88, abril-junio de 1995, págs. 257-272.

23 Andrés Bernáldez, Historia de los Reyes Católicos don Fernando y doña Isabel, Biblioteca de Autores Españoles, Tomo LXX, Madrid, 1953, págs. 655-656. 
cortando los pies, y después que todos los miembros le fueron cortados, sacáronle el corazón por las espaldas y echáronlo fuera de la ciudad, lo apedrearon e lo quemaron en fuego e aventaron la ceniza al viento: llámabase este traidor Juan de Cañamas».

Descanse en paz Juan de Cañamas, él y sus verdugos. Durante siglos no faltaron los defensores de esta justicia inhumana, como el canónigo seviIlano PEDRO DE CASTRO que en 1778 publicó una Defensa de la tortura, el mismo año en que el llustre Colegio de Abogados de Madrid se mostró partidario de mantener esta institución. Pero contra ella se movilizaron en España hombre de la valía de GASPAR DE JOVELLANOS (Representación a Carlos IV sobre lo que era el Tribunal de la Inquisición), VALENTÍN DE FORONDA (Cartas sobre los asuntos mas exquisitos de la Economia Política y sobre las leyes criminales), MANUEL LARDIZÁBAL (que con su Discurso sobre las penas podriamos llamar el Beccaria español ${ }^{24}$ ), etc.

\section{LA CONSTITUCIÓN DE CÁDIZ Y LA FALTA DE UNA DECLARACIÓN EXPRESA SOBRE EL PRINCIPIO DE LEGALIDAD}

Gracias a esa labor de los ilustrados, las ideas reformistas estaban ampliamente difundidas en España a finales del Siglo XVIII; tanto que Carlos III encargó en 1776 "la formación de un Código Criminal, en que se recopilen todas las leyes penales, omitiendo las que no estén en uso, evitando la perplejidad que en las mismas leyes producen por su contrariedad, obscuridad, o variación de costumbres, segun la diferencia de tiempo'» ${ }^{25}$. Sin

24 El título completo es Discurso sobre las penas contraído a las leyes criminales de España, para facilitar su reforma, Madrid 1782 (hay una reedición con excelente estudio preliminar de José ANTON ONECA, REPen, 1967). Salvando las distancias, el éxito de este libro en España fue similar al de Beccaria en Europa, del que es evidentemente deudor, si bien rechazó las propuestas más avanzadas (como la prohibición de la pena de muerte) del italiano. Una idea de su influencia se aprecia, por ejemplo, viendo cómo Marcos GutiérRez se apoya en su autoridad para publicar una obra que "demuestra la necesidad de corregir algunas leyes con el fin laudable de que se corrijan" (Joseph Marcos Gutiérrez, Práctica criminal de España, Madrid, 1804, págs. V-VII).

25 También pedia que "se trate y reflexione sobre el uso de la qüestión del tormento" y que "se considere si la pena capital, que se va ya desterrando en algunos países cultos, se pudiera conmutar en otro castigo de duración para que fuese más permanente el exemplo» [Apud Juan SEMPERE Y GuAainos, Ensayo de una biblioteca española de los mejores escritores del reynado de Carlos III, Madrid, 1785-1789, Tomo III, págs. 172-174]. Sobre los intentos de elaborar un Código penal en el reinado de Carlos III vid. José Ramón CASABO, "Los orígenes de la codificación penal en España: el plan de Código criminal de 1787”, ADPCP, 1969, pág. 313 y ss. 
embargo, el proyecto — redactado por Lardizábal- nunca vería la luz, sin duda porque el Derecho penal era una pieza del gobierno de la Monarquía Absoluta, que no podía ser reformado al margen de ésta. Pero la sustitución del Antiguo Régimen no era una tarea para los reformadores ilustrados y tuvo que esperar a que lo intentaran las Cortes de Cádiz.

Para no alargarnos excesivamente citando hechos y circunstancias bien conocidas, nada diremos aquí del atormentado y glorioso periodo que comenzó con el levantamiento del pueblo de Madrid el 2 de mayo de 1808 contra las tropas francesas y que culminó en Cádiz con la aprobación el 19 de marzo de 1812 de la Constitución política de la Monarquía española ${ }^{26}$. Tampoco nos detendremos en las características generales de este texto: proclamación de la soberanía nacional, rígida división de poderes, mandato representativo, liberalismo exaltado, inexistencia de una expresa declaración de derechos, etc. ${ }^{27}$. Nos limitaremos a señalar los aspectos directamente atinentes a nuestro tema. Para comenzar, el Discurso preliminar, elaborado por AGUSTÍN DE ARGÜELLES, recoge las opiniones penales de Montesquieu y Beccaria, envueltas siempre en la apelación a las antiguas leyes del reino, por lo cual se consideraba muy urgente la elaboración de un Código penal "que represente la imagen de dulzura, de liberalidad y beneficencia que corresponde a la generosidad y grandeza de la nación española» ${ }^{28}$.

Sin embargo, la Constitución misma no contiene una afirmación tan expresa como la del artículo 8 de la Declaración francesa de 1789, lo que le hace decir a Tomás y Valiente que las solemnes y abstractas declaraciones del Discurso preliminar apenas se reflejan en el articulado del texto gaditano porque falta "una enunciación inequívoca del carácter de legalidad previa que debiera tener toda figura delictiva y toda pena" y "se reduce a la enunciación de declaraciones vagas y enfáticas casi nunca traducidas en

26 Cfr., por toda la inmensa historiografía, Miguel ARTOLA, Los origenes de la España contemporánea, IEP, Madrid, 1975, sobre el «levantamiento nacional» vid. Tomo I, pág. 123 y ss.

27 Cfr. Joaquín VARELA SUANCES-CARPEGNA, La teoría del Estado en los orígenes del constitucionalismo hispánico (las Cortes de Cádiz), Madrid, 1983. Manuel MARTínez SospedRA, La Constituciónde1812y el primer liberalismo español, Cátedra FadriqueFurioCeriol, Valencia, 1978; Francisco FERNÁNDEZ SEGADO, Las constituciones históricas españolas, 4. ed., Cívitas, Madrid, 1986, pág.65 y ss.

28 Agustín DE ARGÜELLES, Discurso preliminar a la Constitución de 1812, (edición e introducción de Luis SÁNCHEZ AGESTA), CEC, Madrid, 1981, pág. 110. La apelación constante a la tradición hispánica que hacian los liberales gaditanos se puede apreciar en esta misma página: “Las reglas que establece la Comisión como principios que han de guiar a las Cortes sucesivas en la formación y reforma de código criminal se recomiendan por sí mismas. No son teorías ni seductoras ilusiones de filósofos aislados o novadores. Muchas de ellas están sacadas de las leyes criminales de Aragón y Castilla". 
preceptos constitucionales propiamente dichos" ${ }^{29}$. Sin ánimo de ser irreverentes, como demuestra que hasta ahora venimos siguiendo al gran maestro ad pedem literae, nos permitimos apartarnos de su opinión en este punto concreto, aun a sabiendas de que posiblemente nosotros seamos los equivocados, dada no sólo su excepcional capacidad como iushistoriador sino su "apasionada inclinación por la época y por la obra legislativa de Cádiz».

En nuestra opinión, el severo juicio que hace sobre este punto concreto de la Constitución Tomás y Valiente, se podría dulcificar haciendo un esfuerzo hermenéutico porque en el articulado de la Pepa hay suficientes mimbres como para tejer el cesto del principio de legalidad:

a) El Capítulo III del Título II instituye la división de poderes, que es el substrato previo para que pueda existir el principio de legalidad, de tal forma que la potestad de hacer las leyes reside en las Cortes con el Rey ${ }^{30}$ (art. 15), la potestad de ejecutarlas reside en el Rey (art. 16) y la potestad de aplicar las leyes en las causas civiles y criminales reside en los tribunales establecidos por la ley (art. 17).

b) Las garantías criminal y penal como reserva de ley para fijar los delitos y las penas se puede deducir de esta estricta división de poderes. En la misma dirección apunta tanto el artículo 287, cuando ordena que «ningún español podrá ser preso sin que preceda información sumaria del hecho, por el que merezca según la ley ser castigado" como el 258 que establece que «El Código civil y criminal y el de comercio serán uno mismo para toda la Monarquía". La reserva de ley penal se deduce también, a contrario sensu, de los artículos 172 y 245 ; el primero incluye entre las "restricciones de la autoridad del Rey» la siguiente: «no puede privar a ningún individuo de su libertad, ni imponerle por sí pena alguna»; el segundo determina que «los tribunales no podrán ejercer otras funciones que las de juzgar y hacer que se ejecute lo juzgado» (art. 245).

c) La prohibición de la creación judicial de delitos y penas, la arbitrariedad judicial tan criticada por los ilustrados y que —como vimos más

29 Francisco Tomás y VALIENTE, Manual de Historia del Derecho Español, Tecnos, Madrid, 1979, pág. 531. La referencia que enseguida hacemos sobre su inclinación por la Constitución de 1812 la tomamos de su prólogo a MARTA LORENTE SARINIENA, Las infracciones a la Constitución de 1812, CEC, Madrid, 1988, pág. 13.

30 Téngase en cuenta que el desarrollo de este principio en los artículos 132-152 rompe, a favor de las Cortes, la sensación de paridad que da esta afirmación cfr. Joaquín Tomás VILLARRoYa, Breve historia del constitucionalismo español. 2. ${ }^{a}$ ed., CEC, Madrid, 1982, págs. 22-23. 
arriba- llevó a BECCARIA a negar a los jueces la capacidad de interpretar las leyes, está más que lograda en la Constitución de 1812: «los tribunales no podrán ejercer otras funciones que las de juzgar y hacer que se ejecute lo juzgado" (art. 245); «tampoco podrán suspender la ejecución de las leyes, ni hacer reglamento alguno para la administración de justicia» (art. 246). Al "Supremo Tribunal de Justicia" le corresponde la función de "oír las dudas de los demás tribunales sobre la inteligencia de alguna ley, y consultar sobre ellas al Rey con los fundamentos que hubiere, para que promueva la conveniente declaración en las Cortes" (art. 261.10.).

d) El monopolio judicial para juzgar los delitos (que es la mitad de la garantía jurisdiccional del principio de legalidad) apuntado en el artículo 16, se ratifica en el Título $V$, en sus dos vertientes, activa y pasiva. En la primera, el artículo 242 afirma contundentemente: "La potestad de aplicar las leyes en las causas civiles y criminales pertenece exclusivamente a los tribunales". En la segunda, el artículo 243 prohíbe tanto a las Cortes como al Rey que ejerzan funciones judiciales, y detalla más: ni «avocar causas pendientes, ni mandar abrir juicios fenecidos».

e) La otra mitad de la garantía jurisdiccional, el procedimiento legalmente establecido ante juez competente, está determinado por partida doble: el artículo 244 ordena que «las leyes señalarán el orden y las formalidades del proceso, que serán uniformes en todos los tribunales; y ni las Cortes ni el Rey podrán dispensarlas"; por su parte, el artículo 247 determina que «ningún español podrá ser juzgado en causas civiles ni criminales por ninguna comisión, sino por el tribunal competente determinado con anterioridad por la ley".

Estas disposiciones constitucionales serian suficientes por sí solas para haber derribado el Derecho penal absolutista y cumplir los objetivos del principio de legalidad de garantizar la seguridad jurídica y la libertad de los ciudadanos. Pero la piqueta demoledora del Antiguo Régimen no se detenía aquí: se terminaba con los privilegios nobiliarios en materia de Derecho penal y se abolía el entramado de jurisdicciones de los siglos anteriores (arts. 248), se creaba un nuevo edificio judicial basado en la independencia de los tribunales y en la reserva de ley (arts. 252-279), se extremaban las garantías de los detenidos (arts. 286-300), se ordenaba la publicidad de los juicios (art. 302), se prohibía la tortura (art. 303), etc, etc.

Así las cosas, es verdad que no hay una solemne declaración del principio nullum crimen sine lege, una afirmación tajante de que «nadie puede ser 
castigado sino en virtud de una ley establecida y promulgada con anterioridad al delito y legalmente aplicada» (según la fórmula canónica de la Deciaración de Derechos del Hombre y del Ciudadano); pero esa laguna está más que salvada por el conjunto de artículos de la Constitución que afectan al ius puniendi estata/31. No nos parece, por tanto, demasiado justa la idea de que, en lo concerniente al Derecho penal y a su codificación, el texto gaditano se redujese a afirmaciones vagas con poca transcendencia en normas constitucionales concretas. Antes al contrario, nos atrevemos a afirmar que, en su conjunto, la Constitución de Cádiz era una hija fiel del pensamiento ilustrado sobre el particular, de tal forma que supo traducir Dei delith al ordenamiento jurídico español. Es más, en perfecta coherencia con la división de poderes y con el principio de legalidad únicamente los jueces podian imponer sanciones, con lo que no existía nada parecido a la potestad sancionadora de la Administración: el artículo 172 determinaba que el Rey (titular del poder ejecutivo) «no puede privar a ningún individuo de su libertad, ni imponerle por sí pena alguna". Y es que, como ha señalado Parada, la Constitución pretendía que lo que hoy consideramos funciones represoras no penales estuvieran encomendadas $\sin$ excepciones a los jueces ${ }^{32}$.

Lástima que la vuelta de Fernando VII, el deseado, en 1814 no inaugurase un período constitucional ordinario sino un absolutismo renovado. Por eso, la Comisión designada por las Cortes de Cádiz en abril de 1814 para redactar un Código penal no tuvo tiempo de traspasar los mandamientos constitucionales a la legislación ordinaria ${ }^{33}$ y su trabajo fue extirpado de raíz cuando Fernando VII disolvió las Cortes y declaró en el famoso Manifiesto de 4 de mayo de 1814 «aquella Constitución y tales decretos nulos y

${ }^{31}$ Lo que si se ha perdido completamente en la Constitución de Cádiz (y será una constante en todo nuestro constitucionalismo) es el principio de proporcionalidad, la primera parte del artículo 8 de la Declaración: “La ley no podrá establecer más que penas estrictas y evidentemente necesarias".

${ }^{32}$ José Ramón PARADA VÁZQUEZ, «El poder sancionador en la Administración y la crisis del sistema judicial penal", R4P, núm. 67, 1972, pág. 68-69. Pero el Decreto de 23 de junio de 1813 ya rompió esté monopolio jurisdiccional. al atribuir al Jefe político ejecutar gubernativamente las penas impuesta por las leyes de policía y buen gobierno e "imponer y exigir multas a los que le desobedezcan o falten el respeto, y a los que turben el orden o el sosiego público". Por eso, PARADA afirma que: «en pocas materias resultará, como en ésta, tan significativa la contradicción entre la norma constitucional y la ley ordinaria, e incluso el simple reglamento, y más clara la prueba de nominalismo de nuestras constituciones, de su inoperancia para ser guía y criterio de la redacción de las normas realmente operantes en el comportamiento político y social" (pág. 69).

33 En contra de nuestra opinión, Bartolomé CLAVERo mantiene que «se ultimaron y promulgaron, entre 1804 y 1810, Códigos de las partes más sustantivas del Derecho: un Código civil, un diferenciado Código de comercio o mercantil, y un Código Penal» (Evolución histórica del constitucionalismo español, Tecnos, Madrid, 1984, pág. 24). 
de ningún valor ni efecto, ahora ni en tiempo alguno, como si no hubiesen pasado jamás tales actos, y se quitasen del medio del tiempo" ${ }^{34}$.

\section{LA CONSOLIDACIÓN DEL ESTADO LIBERAL Y LOS PRIMEROS CÓDIGOS PENALES}

En marzo de 1820, gracias al levantamiento de Riego, España volvió a la senda constitucionaly, con ella, a los principios penales de la llustración, que esta vez sí que pudieron plasmarse en un texto normativo: en 1822 se aprobó el primer Código penal español, de cortísima existencia, que Pacheco califico de "científico" y "digno del siglo" ${ }^{35}$. El Código recogía expresamente lo que hemos visto que se podía deducir con facilidad de la Constitución que le daba amparo: el principio de legalidad se consagraba en el artículo 3 donde se establecía que «a ningún delito ni culpa se impondrá nunca otra pena que la que señale alguna ley promulgada antes de su perpetración» ${ }^{36}$. Pero se aparta de un desarrollo estricto de la Constitución (que en el artículo 172 impedía al Rey imponer «penas") para admitir la capacidad sancionadora de la Administración; así, señalaba en su artículo 239 que el Jefe político "no sólo podrá hacer efectivas gubernativamente las penas impuesta por las leyes de policía y bandos de buen gobierno, sino que tendrá facultad para imponer y exigir multas que no pasen de mil reales a los que le

34 Apud Ramón Sainz de Varanda, Colecciones de Leyes fundamentales, Acribia, Zaragoza, 1957, pág. 123. A pesar de los términos tajantes del Decreto, preferimos hablar de un absolutismo renovado porque el golpe de estado de Fernando VII no restableció algunas instituciones del Antiguo Régimen como la tortura, los derechos jurisdiccionales de los nobles y los monopolios comerciales. Hemos tratado varias de estas instituciones en Agustín RUIz ROBLEDO, "La abolición de los señoríos", RDP, núm. 20, invierno 1983-84, pág. 134 y ss. Mucho mejor que nosotros, con caracter general, Miguel ARTOLA, La burguesía revolucionaria, Alianza, Madrid, 1977, pág. 41 y ss. Para el caso concreto de las instituciones penales que abolieron las Cortes de Cádiz y no restableció Fernando VII (otra prueba de que no todo fueron solemnes declaraciones sin transcendencia práctica), vid. Juan Francisco LASSO GAITE, Crónica de la Constitución española. 5 Codificación Penal, Vol I, Ministerio de Justicia, Madrid, s.f. (sobre 1986), pág. 37-39.

35 La cita completa es: «El Código de 1822 es un Código científico. La ciencia del Derecho y la buena filosofía inspiran la mayor parte de sus disposiciones. Digno del siglo, mejoraba inmensamente la situación penal de la nación. Pero a veces es demasiado duro; transige demasiado con antiguas preocupaciones españolas... Hay en él algo del Fuero Juzgo y de las Partidas, envuelto con el carácter del Código de Napoleón» [Apud Francisco TOMÁS Y VALIENTE, Manual... cit. pág. 532].

${ }_{36}$ También son expresión del principio de legalidad los arts. 1 y 2. El CP de 1822 (al igual que todos los posteriores) lo hemos consultado en Jacobo LoPEz BARJA DE QUIROGa et alii, Códigos penales españoles, Akal, Madrid, 1988, pág. 13 y ss. 
desobedezcan o le falten el respeto y a los que turben el orden o el sosiego público, no cometiendo culpas y delitos sobre los cuales se deba formar causa, por tener una pena señalada terminantemente en el Código penal»».

De esta forma, el primer Código Penal configuraba las dos caras del ius puniendi del Estado de una manera que se convertiría en prototípica:

a) Reserva absoluta de ley para los delitos y las penas, cuya aplicación, siguiendo un procedimiento formal, correspondía, en exclusiva a los jueces y tribunales; estos también tenían el monopolio para juzgar las faltas tipificadas en el Código penal.

b) Los reglamentos generales y locales podían tipificar faltas y sancionarlas con multas correspondiendo imponerlas a los Alcaldes y Jefes políticos, que podian proceder sin atenerse a las reglas del procedimiento judicial formal ${ }^{37}$.

El regreso triunfal del Absolutismo en 1823, de la mano francesa de los cien mil hijos de San Luis, supuso otra vez la abolición de la Constitución y la vuelta al viejo Derecho penal del Antiguo Régimen. Poco alteró esta situación el Estatuto Real de 1834, concebido como una Carta otorgada que pretendía estar equidistante tanto del Absolutismo de la Década ominosa como del liberalismo doceañista, con el fin de ganar para la causa isabelina a los liberales más moderados y a las clases altas. Para eso, lo más urgente no era tanto garantizar los derechos fundamentales como imponer un sistema representativo censitario que sirviese para que «la nación legal se identificase con la de los propietarios" ${ }^{38}$.

Así, hubo que esperar a que el motín de la Granja de agosto de 1836 proclamase de nuevo la Constitución de Cádiz para que volviese, al menos a nivel constitucional, el Estado de Derecho y el principio de legalidad. Las Cortes emanadas de la convocatoria electoral se aprestaron a reformar la Constitución - considerada por la mayoría demasiado exaltada - y elaboraron una Lex legum que con palabras de hoy llamariamos transaccional entre

37 Cfr. Alejandro NIETo, Derecho Administrativo Sancionador, cit. pág. 50. Una opinión distinta es la mantenida por José Ramón PARADA VÁzQuEZ, si bien este autor nada dice sobre los términos indubitados del artículo 239 (que hemos transcrito en el texto) y se limita a negar la potestad sancionadora de la Administración argumentando que el artículo 138 no establecía una previsión de esta potestad, sino que estaba referido a las jurisdicciones militar y eclesiástica ( EEl poder sancionador..." cit., pág. 70).

38 Joaquín Tomás VIllarroya, El sistema político del Estatuto Real (1834-1836), IEP, Madrid, 1968, págs. 127 y (sobre el sistema electoral) 427 y ss. 
las dos ramas de liberalismo (moderados y radicales): se atenúa el principio de soberanía nacional (que sólo aparece en el Preámbulo), se instaura el bicameralismo, desaparecen algunos derechos, etc. ${ }^{39}$.

En el aspecto que a nosotros más interesa, los principios constitucionales del Derecho penal, esta Norma normarum mantuvo las garantías de la de 1812: división de poderes, reserva a los tribunales de la aplicación de las leyes criminales "sin que puedan ejercer otras funciones que las de juzgar y hacer que se ejecute lo juzgado" (art. 63), unidad de Códigos y de fueros para todos los españoles (art. 4), publicidad de los juicios criminales (art. 65), independencia y responsabilidad de la Justicia (arts. 66-67), etc. La única ausencia relevante que se advierte es el mandato del artículo 261 de la Constitución de Cádiz, que obligaba a los tribunales a presentar las dudas que tuvieren sobre « la inteligencia de alguna ley» para que éste instara la "conveniente declaración de las Cortes". Sin duda, la experiencia de otros Estados liberales europeos convenció a los constituyentes de lo impracticable que era prohibir a los tribunales la interpretación de las leyes. En fin, lo que si contenía la Constitución de 1837 era una expresa afirmación del principio nullum crimen sine lege: "Ningún español puede ser procesado ni sentenciado sino por el Juez o Tribunal competente, en virtud de leyes anteriores al delito y en la forma que estas prescriban» (art. 9).

La muy moderada Constitución de 1845 (que tanto templó a la ya de por sí templada Constitución de 1837) mantuvo intacto el principio de legalidad, tanto que no cambió ni una coma del artículo 9 y mantuvo todas sus garantías conexas ${ }^{40}$. $Y$ es que a esas alturas del siglo $\mathrm{XIX}$, se trataba de un dogma

39 Cfr. Antonio COLOMER VIADEL, El sistema político de la Constitución española de 1837, Congreso de los Diputados, Madrid, 1989.

40 Para ser exactos, abrió una pequeña brecha en la separación de poderes y en el monopolio juzgador de los tribunales: el artículo 19 atribuyó al Senado la capacidad de juzgar a sus miembros, a los ministros y a los autores de «delitos graves contra la persona o dignidad del Rey, o contra la seguridad del Estado, conforme a lo que establezcan las leyes". Sin embargo, Alejandro NiETo piensa que la Constitución de 1845 "ya no insiste en la división de poderes, degrada el Poder Judicial a simple aparato de 'la administración de la justicia' y acepta con normalidad (no como excepción) las potestades sancionadoras de la Administración". Es muy difícil compartir esta opinión ya que si bien es verdad que en la Constitución de 1837 el Título X se denomina «Del Poder Judicial» mientras que en la del 45 se llamará "De la Administración de Justicia" (como la muy separadora de poderes de 1812), lo cierto es que ambos títulos tienen siete artículos completamente idénticos. Lo mismo podemos decir de las competencias del Rey: la Constitución de 1845 sigue punto por punto a la de 1837, por lo que no liegamos a imaginarnos cómo puede ser que teniendo el mismo articulado, de una se derive un poder administrativo sancionador normal y de la otra excepcional. Una comparación detallada entre las dos Constituciones, que aceptamos plenamente, es la de Antonio TORRES DEL MORAL, Constitucionalismo histórico español, 3. ed, Atomo, Madrid, 1990, pág. 84 y ss. 
que habia pasado a ser un acervo común de todas las tendencias políticas: el Estado Absoluto había fenecido y con él la arbitrariedad del Derecho Penal. Bajo esta Constitución moderada se aprobó un nuevo Código penal, el de 1848. Los especialistas de Derecho penal suelen resaltar que se trata de un código muy técnico, tanto que su estructura ha pasado a todos los posteriores, que comparado con el de 1822 es más severo, si bien volvía a consagrar en términos indubitados, el principio de legalidad penal (arts. 1, 2, 19 y 87).

Sin embargo, desde el punto del vista del Derecho constitucional, la diferencia más importante que debemos señalar radica en su forma de elaboración: mientras el Código de 1822 fue «decretado" por las Cortes, partiendo de un proyecto elaborado por una Comisión del órgano legislativo (en la que Calatrava y Martínez Marina tuvieron el protagonismo); el de 1848 partió del poder ejecutivo, que casi monopolizó su elaboración y aprobación. Así en agosto 1843, sólo un mes después de la caída de Espartero, el nuevo Gobierno conservador creó la Comisión General de Codificación, que se dividió en cuatro secciones (civil, penal, procesal civil y procesal criminal) para elaborar los respectivos proyectos legislativos; la penal, bajo la presidencia de Seijas Lozano, redactó un proyecto de Código penal que elevó al Gobierno el 24 de diciembre de 1845; allí languideció hasta que éste lo presentó el 13 de febrero de 1847 al Senado, con la idea de que se aprobase mediante una ley de autorización; pero fue un nuevo Gobierno (presidido por el muy autoritario general Narváez) el que activaría su tramitación y entonces no se planteó solamente que las Cortes autorizarán el Código remitido por el Gobierno ${ }^{41}$, sino que además la ley de autorización incluyera un artículo para que el gobierno hiciera "por sí cualquiera reforma, si fuere urgente, dando cuenta á las Córtes tan pronto como sea posible" ${ }^{42}$. Al amparo de esta delegación genérica, el

41 Si se nos permite el anacronismo, el procedimiento recuerda el actual iter de lectura única: las Cortes, a la vista del proyecto de CP, debieron decidir si lo aprobaban o rechazaban in totum renunciando a debatir artículo por artículo, para evitar - según razonó la Comisión del Senado- que «la discusión completa del proyecto destruya con enmiendas incoherentes la unidad y armonía del Código". A esta argumentación sólo se opuso el senador José Alonso “por ser indelegables las atribuciones parlamentarias y porque si no son aptos para discutir el Código o sus bases, tampoco lo serán para dar la autorización para que ese Código se plantee". Una exhaustiva exposición de la tramitación, que aquí apenas esbozamos, puede verse en Juan Francisco LASSO GAITE, Crónica de la codificación... cit, págs. 251-390 (las citas que realizamos son, respectivamente, de las págs. 310 y 313).

42 Artículo 3 de la Ley de 19 de marzo de 1848 . El mismo día se aprobó el Real Decreto con el Código Penal. El Gobierno empleó abundantemente la autorización genérica para reformar el Código. Así en el mismo año 1848 aprobó el RD de 21 de septiembre sobre reforma de varios artículos del CP, el RD de 22 de septiembre upor el que se aclaran dudas en algunos artículos del CP», el RD de 30 de octubre dejando en suspenso el artículo $183 \mathrm{CP}$, etc. Cfr., Juan Francisco LASSO GAITE, Crónica de la codificación española, cit, Vol. II, pág. 1128. 
Gobierno redactó un nuevo Código en 1850, que ya sólo se presentó a las Cortes a posteriori, sin que éstas lo votasen ${ }^{43}$, y que contenía un artículo que evaporaba una de las garantías del principio de legalidad, la garantía penal, la reserva de ley para fijar las penas: «No será castigado ningun delito, ni las faltas de que solo pueden conocer los Tribunales, con pena que no se halle establecida previamente por ley, ordenanza ó mandato de Autoridad á la cual estuviere concedida esta facultad ’ (art. 19).

Incluso olvidándonos de este último artículo, el hecho de que el Gobierno elaborase, material y formalmente, el Código penal contradecía por completo la clásica construcción teórica del principio de legalidad, que concebía la reserva de ley como reserva de Parlamento, sin posibilidad de delegación de la potestad legislativa en el ejecutivo (facultad por lo demás no prevista en la Constitución de 1845), tal y como se había respetado escrupulosamente en 1822. Un cuarto de siglo después, en 1848 y -sobre todo- en 1850, el principio de legalidad penal quedaba reducido a una reserva de norma escrita, a una exclusión del derecho consuetudinario de las fuentes del derecho penal. El cambio de 1822 a 1850 se hizo a pesar de que en la Constitución de 1845 había una mención expresa a la reserva de ley penal (ausente en la de 1812) y a que el Código estaba repleto de referencias a la «ley». Por eso, esta transformación ha sido invisible para muchos investigadores ${ }^{44}$, que no han advertido que detrás de las solemnes declaraciones de ambos textos, la Constitución y el Código, latía la realidad de un Derecho penal elaborado por el Gobierno.

43 LASSO Gaite señala que el Real Decreto de 7 de junio de 1850 se dictó al amparo del artículo 2 de la Ley de 19 de marzo de 1848 que ordenaba que «El Gobierno propondrá á las Córtes dentro de tres años, $\delta$ antes si lo estimare conveniente, las reformas ó mejoras que deban hacerse en el Código, acompañando las observaciones que anualmente por lo menos deberán dirigirle los Tribunales" [Juan Francisco LASso GaiTE, Crónica de la codificación... cit, Vol. I, pág. 318]. Nos permitimos discrepar de este documentadísimo trabajo ya que, si bien es verdad que el gobierno recibió numerosas sugerencias de los tribunales, no propuso el Código (tal y como ordenaba ese art. 2), sino que lo aprobó directamente dando cuenta luego a las Cortes (tal y como se lee tanto en la exposición de motivos del RD como en el art. 3 de la Ley). No hubo aquí, por tanto, nada parecido a un procedimiento de lectura única y sí una pura y simple deslegalización.

44 Cfr., por ejemplo, un trabajo de excepcional calidad como el de José M." BAÑo LEÓn, LOS límites constitucionales de la potestad reglamentaria (Remisión normativa y Reglamento independiente en la Constitución de 1978), Cívitas, Madrid, 1991, en el se afirma que "Se observa en el conjunto del ordenamiento español del siglo XIX que todas las normas referente a libertades o derechos fundamentales tienen como referencia básica una ley. Las Asociaciones, la libertad de imprenta, la organización de los Tribunales, los sucesivos Códigos tanto penales como mercantiles, el Código Civil, las normas sanitarias y un largo etcétera se regulan por ley" (pág. 79). Evidentemente, sí que no le pasó inadvertido el nuevo método para elaborar los Códigos a Francisco TOMÁs Y VALIENTE, Códigos y Constituciones (1808-1978), Alianza, Madrid, 1989, págs. 20 y ss. 
Sin duda, esta nueva forma de concebir el principio de legalidad (propiciada por la falta de normatividad de la Constitución ${ }^{45}$ ) puede basarse en las razones de funcionamiento que entonces se dieron, la superioridad de un pequeño grupo de expertos sobre una gran Asamblea, incapacitada para elaborar y discutir una «legislación científica» ${ }^{46}$. Sin embargo, nos parece que hay otra razón más profunda, extrajurídica: en 1812 y 1822 entender el principio de legalidad como reserva de Parlamento suponía que la burguesía revolucionaria se reservaba para sí misma un instrumento nada despreciable de la lucha política, quitándoselo al Rey, que todavía conservaba en la Lex legum de 1812 el poder ejecutivo; pero en la década moderada de 1843-54 ese antagonismo entre los poderes había desaparecido, la jovencísima Isabel II no estaba preocupada, precisamente, por gobernar y su Gabinete (a pesar de la inestabilidad endémica) estaba controlado por la misma fuerza social que dominaba la Cortes: la alianza entre nobleza y burguesía conservadora. Precisamente, no puede ser casual que el artículo tres de la Ley de autorización (permitiendo que el Gobierno reformase el Código sin intervención previa de las Cortes) se introdujera a instancias del muy autoritario General Nárvaez, que de esa forma ponía en manos del Gobierno conservador un rápido instrumento para punir las conductas contrarias a sus

45 Siempre que aceptemos que las Constituciones decimonónicas establecían auténticas reservas de ley, cuestión sobre la que existe una tradicional polémica doctrinal. Cfr. a favor, Lorenzo MARTín RETORTILLO, "La doctrina de las materias resenvada a la ley y la reciente jurisprudencia del Tribunal Supremo", RAP, núm. 39, 1962, pág. 292 y ss. En contra, Alfredo Gallego ANABITARTE, Ley y reglamento en el Derecho Público occidental, Madrid, 1971, págs. 33 y ss.

46 Además de las citas del DSC de la nota 41 puede recordarse ahora el preámbulo del Decreto del Gobierno provisional de 19 de agosto de 1843 creando la Comisión General de Codificación: "preocupado el ánimo de los gobernantes y de los cuerpos colegisladores con las amargas vicisitudes de la guerra civil y la agitación de las cuestiones políticas, poco ha adelantado hasta ahora en la grande obra de la codificación, atraso lamentable y en gran parte debido al sistema empleado en los trabajos preparatorios". Desde luego - y siguiendo la tradición espańola de inmortalidad de las decisiones provisionales - la idea no ha debido ser especialmente equivocada dado que la Comisión General de Codificación ha sobrevivido hasta la fecha. Por su parte, los Reglamentos parlamentarios decimonónicos también reconocieron la especialidad de los Códigos e idearon normas particulares para su tramitación legislativa. Así, por ejemplo, los proyectos de Códigos podían dar lugar a "varias discusiones generales sobre los diversos libros o títulos que comprendan" (art. 101 del RC de 14 de febrero, que copiaron todos los posteriores) y eran los únicos que no decaían al terminar la legislatura o (en la expresión histórica) «diputación» (art. 92 del RC de 4 de mayo de 1847 y RR siguientes). En el plano doctrinal, en 1836 PACHECo defendió que los Códigos debian ser obra de especialistas porque cunos cuerpos numerosos como nuestras cámaras son los menos aptos para la formación de semejantes leyes" [Estudios de legislación y jurisprudencia, Madrid, 1843, pág. 25]. Una cita más completa de esta idea de Pacheco, con agudos comentarios, puede verse en Francisco TOMÁS Y VALIENTE, "Estudio preliminar» a Joaquín Francisco PACHECO, Lecciones de Derecho político, CEC, Madrid, 1984, pág. XXXIl y ss. 
intereses, como se advirtió en la reforma de 1850 en la que se castigaba con más severidad ciertos delitos políticos, muy especialmente la conspiración ${ }^{47}$.

En fin, en la misma línea de aumentar la capacidad represora de las autoridades administrativas, el mismo Código penal de 1850 reconocía expresamente en su artículo 505 la potestad sancionadora de las Administraciones públicas:

«En las ordenanzas municipales y demás reglamentos generales ó particulares de la Administración que se publicaren en lo sucesivo, no se establecerán mayores penas que las señaladas en este libro ["De las faltas"], aun cuando hayan de imponerse en virtud de atribuciones gubernativas a no ser que se determine otra cosa por leyes especiales. Conforme a este principio, las disposiciones de este libro no excluyen ni limitan las atribuciones que por las leyes de 8 de enero, 2 de abril de 1845 y cualesquiera otras especiales competan a los agentes de la Administración para dictar bandos de policía y buen gobierno y para corregir gubernativamente las faltas en los casos en que su represión les esté encomendada por las mismas leyes» ${ }^{48 .}$

De esta forma, no es del todo cierto la idea tan difundida en la doctrina de que en 1850 se consolida un sistema bipunitivo caracterizado por la estricta reserva de ley para las sanciones penales, mientras se admite que las administrativas puedan recogerse en los reglamentos, siempre que tuviesen cobertura legal o justificación necesaria ${ }^{49}$. Tanto el grueso de las normas penales como el de las administrativas lo realizaba el Gobierno, con la diferencia de que en el primer caso los Decretos que las aprobaban se denominaban "Código penal" y en el segundo «Reglamentos» 50 . Por eso, puestos a buscar diferencias según los órganos estatales implicados, el sistema bipunitivo del siglo XIX no se puede diferenciar tanto por los órganos productores, como por los aplicadores: lo característico del Derecho penal consistía en que el monopolio de su aplicación

47 Cfr. una opinión similar (aunque sin referirse al principio de legalidad) en Francisco TOMÁS Y VALIENTE, Manual... cit, pág. 535.

48 Citamos por Jacobo BARJA DE QUIROGA et alĭ, Códigos penales españoles, cit., pág. 448. Sobre la peripecia de este artículo 505, cfr. José Ramón CASABÓ RUIZ, "La capacidad sancionadora de la Administración en el proyecto de Código penal" en VVAA La reforma penal y penitenciaria, 1980 , págs. 277 y ss.

49 Cfr., por toda la doctrina, Alejandro Nieto, Derecho Administrativo Sancionador, cit., pág. 52 y ss. Sí que seguimos plenamente a este autor en su opinión sobre los conflictos de jurisdicción entre los órganos sancionadores administrativos y los penales (pág. 56 y ss.), a los que enseguida nos referiremos en el texto.

50 Las Cortes aparte de la Ley de autorización de 1848 (y otras que veremos enseguida) también intervinieron en el Derecho penal mediante las Leyes especiales. En el caso de la potestad administrativa sancionadora el Gobierno no tenía su monopolio dado que también se le reconocía profusamente esta capacidad a los Ayuntamientos. 
estaba íntegramente en manos de los jueces y tribunales, si bien es verdad que abundaron los conflictos entre la Administración y los Tribunales, dado que el Código penal y los reglamentos tenían muchos tipos coincidentes.

\section{DE LA GLORIOSA A LA II REPÚBLICA}

La técnica de constitucionalizar el principio de legalidad y luego permitir por vía legislativa que el Gobierno elaborara y aprobara el Código penal fue ya una constan te de nuestra Historia constitucional. Así, cuando la Gloriosa terminó con la época moderada y se redactó la Constitución de 1869, la primera auténticamente democrática (instauró el sufragio universal masculino), con su generosa declaración de derechos, na da innovó en relación con el principio de legalidad. Lo único que hizo fue darle una redacción ligeramente más confusa que la establecida en 1837, sin duda movido por la intención de establecer claramente en un mismo artículo tanto una reserva de ley penal como de ley procesal: «Ningún español podrá ser procesado ni sentenciado sino por el Juez o Tribunal a quien, en virtud de leyes anteriores al delito, competa el conocimiento y en la forma que éstas prescriban". Igualmente, se sigue la práctica de 1848 y las propias Cortes Constituyentes autorizaron en la Ley de 17 de junio de 1870 al Gobierno para que elaborase un nuevo Código penal, donde se vuelven a recoger las distintas garantías del principio de legalidad ${ }^{51}$.

51 La forma de elaborar este Código fue muy similar a la de 1848: la Comisión de Codificación preparó un proyecto que el $\mathbf{3 0}$ de mayo de 1870 fue elevado a las Cortes para que lo aprobase mediante una ley de autorización, técnica que tenía cierto apoyo en el artículo 52 de la Constitución, que excepciona a los Códigos de votarse artículo por artículo, si bien añade tajante: "pero, aun en este caso, los respectivos proyectos se someterán íntegros a las Cortes". Por eso, y también como en 1848, se alzó alguna voz -como la del diputado de la Unión Liberal González Marrón— impugnando el procedimiento «porque era anticonstitucional el sistema de autorizaciones legislativas, tan criticado por miembros del Gobierno desde la oposición en años anteriores». Quizás para soslayar este tipo de crítica el Código se planteó como una «ley provisional». Vid. Juan Francisco LASSO GAITE, Crónica de la codificación española, cit., Vol I, pág. 459. Aunque por este procedimiento de la autorización se hurtase a las Cortes un debate artículo por artículo del Código, no cabe duda de que sus autores tenían la intención de sustituir el muy conservador CP por otro más respetuoso con los derechos individuales y el Estado de Derecho. La superioridad sobre el de 1848 lo reconocieron incluso su propios detractores en las Cortes Constituyentes, como Silvela y Sánchez Ruano. Por el contenido que a nosotros interesa debemos señalar que, además de recoger las garantías tradicionales del PL (arts. 1, 2 y 22), establecía en el art. 23 por vez primera el principio de retroactividad de la ley sancionadora favorable. Otra característica importante de este Código era el detalle con el que regulaba la concreción de las penas, que dejaba a los jueces casi sin margen para individualizarlas. Sin duda, esa «aritmética penal» respondía a una concepción del principio de legalidad como garantía frente a la arbitrariedad de los juzgadores; cfr. Manuel CoBo et alii, Conmemoración del centenario de la Ley Provisional sobre organización del poder judicial y del Código penal de 1870, Madrid, 1970. Una crítica doctrinal al «reducido arbitrio judicial» puede encontrarse en José ANTÓN ONECA, «El Código penal de 1870n, ADPCP, 1970, pág. 250. 
Por su parte, la Constitución de 1876, que tantos derechos generosamente proclamados por la de 1869 cercenó ${ }^{52}$, no introdujo ningún cambio en el principio de legalidad, salvo en la forma, pues siguió a la Constitución de 1837, de tal manera que hizo desaparecer cualquier duda sobre la lex proevia penal: «Ningún español puede ser procesado ni sentenciado sino por el Juez o Tribunal competente, en virtud de leyes anteriores al delito, y en la forma que éstas prescribieran" (art. 16). En el ámbito legal no modificó substancialmente el Código de 1870, que se mantuvo con la leve reforma de la Ley de 17 de julio de 1876 hasta que la Dictadura de Primo de Rivera, fiel al principio de que cada régimen político necesita su propio Código penal, lo sustituyó en 1928 por otro de carácter autoritario. Éste, muy criticado tanto por la excepcional severidad de sus penas como por algunos defectos técnicos, tampoco modificó el principio de legalidad (arts. 1, 2 y 7), y recibió el beneplácito de la doctrina en un punto concreto: incorpora al Derecho penal español las medidas de seguridad, «más confiadas que las penas al arbitrio judicial, que la más exacta individualización y apreciación de las causas de inimputabilidad y de justificación, de las circunstancias de las infracciones y de las condiciones de los infractores, indica como de notoria conveniencia» ${ }^{53}$.

Ahora bien, por mucho que formalmente el Código de 1928 consagrase el principio nullum crimen, nullum poena sine proevia lege, incluso con la prohibición expresa de la interpretación extensiva ${ }^{54}$, lo cierto es que le faltaba el presupuesto básico del principio de legalidad: el Estado de Derecho y la división de poderes, sin que ni siquiera se pueda incluir dentro de la versión atenuada que venimos viendo, de una autorización previa de una Cortes más o menos representativas, ya que fue aprobado por el Real Decreto-Ley de 8 de septiembre (posteriormente corregido por otro de 10 de diciembre) ${ }^{55}$.

52 Lo hizo, básicamente, por la técnica de diferir su eficacia hasta la aprobación de las leyes de desarrollo: «Las leyes dictarán las reglas oportunas para asegurar a los españoles en el respeto recíproco de los derechos que este título les reconoce, sin menoscabo de los derechos de la Nación, ni de los atributos esenciales del Poder público" (art. 14); cfr. Remedio SÁNCHEZ FERRIZ, La Restauración y su Constitución política, Universidad de Valencia, 1984, págs. 238 y ss.

53 De la Exposición de Motivos, que hemos consultado en Jacobo LóPEZ BARJA DE QUIROGA et alii, Códigos penales españoles, cit., pág. 681. Quien criticó con excepcional dureza este «engendro de la dictadura" fue Luis JIMÉNEZ DE ASÚA, Tratado de Derecho penal, cit., Tomo I, pág. 726 y ss.

54 «Art. $2^{\circ}$ No se admitírá la ínterpretación extensiva, ní tampoco la analogía o semejanza, para definir delitos o faltas, o agravar penas".

55 El sistema de elaboración fue, a grandes rasgos, el siguiente: La «Comisión de códigos» elaboró un proyecto de CP que el Gobierno envío en noviembre de 1927 a la "Asamblea Nacional» para que lo dictaminara, lo que hizo su "Sección 5." ", que terminó su trabajo en marzo de 1928. Posteriormente, el Ministro de Gracia y Justicia Galo Ponte con el asesoramiento de los catedráticos 
El 14 de abril de 1931 se proclamó la II República española. Al día siguiente, el Gobierno provisional presidido por don Niceto Alcalá-Zamora publicó un decreto anulando (y no simplemente, derogando) el Código penal de 1928 por lo que entró en vigor el antiguo Código penal de $1870^{56}$. En un momento en que no existían todavía Cortes, el principio de legalidad, siempre presente en la conciencia jurídica moderna, causó el siguiente dilema: para punir en 1931 la mayoría de los delitos contra la seguridad del Estado, que en el Código de 1870 se referían a la Monarquía, había que elegir entre dos violaciones del principio de legalidad: o aplicar la analogía (en contra de la lex certa) o modificar el Código por Decreto (en contra de la reserva de ley formal). Con buen criterio, y el inteligente asesoramiento de Jiménez de Asúa, el Gobierno eligió la menos nociva: por Decreto de 2 de mayo de 1931 introdujo las reformas necesarias para republicanizar el Código de 1870 y hacerlo compatible con la nueva forma de Gobierno ${ }^{57}$.

La elaboración de la Constitución de 1931 no fue, precisamente, un modelo de consenso y muy pocos artículos pasaron sin controversia por las Cortes Constituyentes. Pues bien, uno de éstos artículos que podríamos llamar -empleando un anacronismo- de consenso fue el 28 , que recogía el principio de legalidad, tanto es así que su tramitación no dio lugar a enmienda alguna y —según cuenta LUIS JIMÉNEZ DE ASÚA— se aprobó sin debate ${ }^{58}$.

Cuello Calón y Jiménez Vicente modificó el proyecto, que fue presentado al Consejo de Ministro el 25 de agosto y publicado el 8 de septiembre para que entrara en vigor el 1 de septiembre de 1929 [Cfr., una vez más, el exhaustivo trabajo de Juan Francisco LASSO GaITE, Crónica de la codificación española, cit., Vol I, págs. 657-716). No es ocioso señalar, como nueva prueba de la particular forma de entender el PL que tenía la dictadura, que el Decreto aprobando el CP autorizó al Ministro de Justicia a dictar «cuantos Reales decretos, Reales órdenes, Reglamentos y demás disposiciones sean convenientes para la ejecución de las penas que en dicho Cuerpo legal se establecen y para el más exacto y fácil cumplimiento de cuantos preceptos contiene el mismo" (art. 2).

56 El Decreto anuló el CP de 1928 «Por haber sido uno de los mayores desafueros dictatoriales, contrario a los principios básicos de cultura jurídica, el uso y abuso sistemático de las Ordenanzas penales, absolutamente nulas, el Gobierno de la República, recogiendo las protestas casi unánimes que contra ese atentado a la libertad y a los principios jurídicos habian formulado la opinión pública y las colectividades profesionales, decreta los siguiente: Art. 1 Queda anulado, sin ningún valor ni efecto, el titulado Código penal de 1928. Igual declaración de nulidad se extiende a todos los titulados DecretosLeyes de la Dictadura, que establecieron o modificaron definición de delitos o fijación de penas».

57 Sobre esta forma de republicanizar el CP de 1870 y, en general, sobre la legislación penal de la República, cfr. además del inevitable Juan Francisco LASSO GAITE (op. cit., T. I, págs. 750 y ss.), el testimonio directo de uno de sus máximos autores, Luis JIMÉNEZ DE AsúA, Tratado de Derecho penal, cit., T. I, pág. 730 y ss.

58 Luis Jiménez DE AsÚA, Proceso histórico de la Constitución de la República Española, Reus, Madrid, 1932, pág. 223. Su texto es el siguiente: “Sólo se castigarán los hechos declarados punibles por ley anterior a su perpetración. Nadie será juzgado sino por juez competente y conforme a los trámites legales". 
Por eso, extraña sobremanera la ácida crítica que en 1936 le dedicó don NICETO ALCALÁ-ZAMORA:

«El artículo 16 de la Constitución de 1876 tenía concisión lapidaria, texto clarísimo, garantía suprema, total, triple: de orden penal, exigiendo la ley previa para apreciar el delito; de organización judicial, el juez o tribunal competente, de trámites procesales. No cabía decir más con menos y mejores palabras; [...] Se desechó la redacción porque figura en la Constitución de 1876 y sucedió lo que sucede siempre que se retoca una fórmula que constituye hallazgo de acierto insuperable: que fue mucho más largo, menos preciso, peor redactado, con distinta inferior claridad, y a la vez elegancia, el artículo 28 de la Constitución vigente. [...] con toda la valía mental y oratoria de Olózoga, de Cánovas y de los colaboradores de uno y otro, todos ellos juntos, y dicho sea sin agravio y sin adulación, sabian mucho menos derecho penal que el insigne profesor presidente de la Comisión dictaminadora en 1931 [Jiménez de Asúa]. Pero como la meta del acierto estaba alcanzada, y había que separarse de ella por figurar en la Constitución de 1876, el resultado era inevitable, aun con toda esa superioridad de preparación y saber: quedarse atrás, con una redacción peors ${ }^{59}$.

En nuestra modesta opinión, y faltos de apoyos sólidos, nos atrevemos a especular que la redacción que recibió el principio de legalidad en 1931 se debió, como ya había sucedido en la Constitución de 1869, al deseo de que quedaran claramente expresadas tanto la reserva de ley penal como la reserva de ley procesal, por lo que se optó por escindir en dos frases lo que anteriormente se decía en una sola. Si no se puede admitir, sin más, la opinión de Alcala-Zamora de que se actúo así para separarse de la Constitución de 1876 (se trata de un artículo que fue propuesto por la Comisión Jurídica Asesora y no por Jiménez de Asúa) sí que hay que estar de acuerdo con su opinión de que el principio de legalidad quedó peor redactado en el texto de 1931 que en el de 1876 (copia del de 1837), sobre

59 Niceto AlCALA-Zamora, Los defectos de la Constitución de 1931, cit, págs. 59-60. Don Niceto parece echar la culpa de la redacción definitiva a la Comisión (con la que se enfrentó en más de una ocasión en los debates constituyentes, como recogen tanto él mismo como Jiménez de Asúa en el libro citado en la nota anterior); pero en verdad el texto lo había propuesto la Comisión Jurídica Asesora, a la que el Ex-presidente de la República, lejos de atribuir ningún deseo de apartarse de los precedentes conservadores, dedica grandes elogios (págs. 38-39). Así, Nicolás PÉrez Serrano escribió que el art. 28 «es transcripción del que figuraba como 13 en el Anteproyecto". Don Nicolás no olvidó una certera crítica en sus Comentarios a aigo con más transcendencia: «resulta más doloroso que una Ley grave, como la de 21 de octubre de 1931 [la Ley de Defensa de la República], no siga el criterio clásico de la definición precisa de los hechos punibles" (La Constitución española, Editorial de Revista de Derecho Privado, Madrid, 1932, pág. 145). Vid. también la crítica que de esta ley y de su sucesora, la Ley de orden Público de 1933, hace José Ramón PARADA VÁzQUEZ, «Evolución y constitucionalización de las infracciones administrativas", $P J$, núm. 4, septiembre de 1982, págs. 21-22. 
el que únicamente cabía hacer la mejora apreciable de sustituir «español» por «persona».

En fin, con mejor o peor estilo, lo cierto es que la Constitución de 1931 volvió a consagrar el principio de legalidad y a su cobijo en 1932 se pensó en la elaboración de un nuevo Código penal, lo que se planteó en dos etapas: una primera de reforma del Código de 1870 y, posteriormente, una segunda de elaboración de un nuevo texto. Los avatares de la II República originaron que no se pasara de la primera fase, que se encargó a la Subcomisión de Leyes Penales de la Comisión Jurídica Asesora del Gobierno, presidida por Luis Jiménez de Asúa, a la sazón diputado socialista y catedrático de Derecho Penal. La reforma, materialmente, no afectó al principio de legalidad (que se mantuvo en los arts. 1 y 22) y se limitó a adaptar el Código a la Constitución republicana suprimiendo algunos delitos que ya no tenían razón de ser (como el de usurpación de títulos nobiliarios) y humanizando las penas (supresión de la pena de muerte). Ahora bien, desde la perspectiva formal debemos resaltar que la reserva de ley volvió a entenderse de una manera relativa: como una reserva de parlamento que éste podía delegar en el Gobierno. En efecto, las Cortes aprobaron un proyecto de Ley de Bases, que se discutió en una única y veloz sesión, el 6 de septiembre de 1932 y el Gobierno aprobó el correspondiente decreto con el texto articulado el 5 de noviembre de 1932, que entró en vigor el 1 de diciembre del mismo año.

Ahora bien, si en ocasiones anteriores, la intervención del Gobierno se había realizado al margen de la Constitución, no sucedió así en la II República porque su Norma normarum había recogido expresamente la posibilidad de que las Cortes autorizaran al Poder Ejecutivo para que "éste legisle por decreto, acordado en Consejo de Ministros, sobre materias reservadas a la competencia del Poder legislativo" (art. 61). Debemos ratificar aqui la opinión que venimos manifestando sobre el porqué de no considerar el principio de legalidad como una estricta reserva de Parlamento: tanto este principio como la rigurosa división de poderes tienen especial razón de ser en el Estado liberal clásico, la monarquía constitucional, cuando el poder legislativo se sustentaba en una legitimidad distinta (la elección) de la que tenía el poder ejecutivo (que se residenciaba en el Rey), pero se atenúan en la monarquia parlamentaria, cuando el Rey pasa a ser únicamente el Jefe del Estado y el Gobierno es responsable ante el Parlamento. Solamente se excluirá esta posibilidad de delegación cuando el principio de legalidad, y en general cualquier reserva de ley, pase a concebirse no tanto una técnica de relación entre los poderes estatales como 
una estricta garantía de los ciudadanos (lo que sucede en la Constitución de 1978$)^{60}$.

Si el principio de legalidad se concebía sólo como un instrumento de lucha de las Asambleas frente al Monarca, todavía tendrá menos sentido que en la Monarquía parlamentaria en un Estado de partidos, tal como era el republicano, donde la contienda política se producía entre el Gobierno y la Oposición. Esta contraposición, unida a la nueva complejidad de la actividad estatal, transforma las relaciones de enfrentamiento entre los poderes en unas relaciones de colaboración, con predominio del Ejecutivo, como muy bien supo ver en aquella misma época Mirkine-Guetzevitch ${ }^{61}$. Además, en 1932 se le podía añadir una razón de tipo estrictamente política: en una época de grandes reformas (y no menores enfrentamientos) sociales, un nuevo Código penal no pasaba de ser un objetivo muy secundario en las preferencias de los 470 diputados y más de 20 partidos con representación en las Cortes ${ }^{62}$. Una buena prueba de esa preferencia parlamentarias es que la segunda fase de la reforma, un Código más pausado, nunca se llevase a efecto.

60 La razón reside en el procedimiento legislativo, que es el único en el que se producen debates plenamente contradictorios y una amplia publicidad, por lo que es el que mejor garantiza los derechos de los ciudadanos; idea esta que fue defendida por M. GASTÓN JĖZE en la reunión del Instituto Internacional de Derecho público de 1929 («Les libertés individuelles", Annuaire de IInstitut International de Droit public, París, 1929, págs. 162 y ss.). Para la doctrina actual, cfr. Francisco RuRBIO LLORENTE, "La ley como garantía de los derechos de los ciudadanos" en La forma del poder (Estudios sobre la Constitución), CEC, Madrid, 1993, pág. 377 y ss.

61 «Las indicaciones [sic] complicadas de la vida actual transtorman las relaciones entre el Legislativo y el Ejecutivo. Es el período en que lucha la democracia con el Poder real; el centro de gravedad radicaba en el control del Parlamento: la lucha del Parlamento contra el Poder real. Pero en una democracia esta lucha no existe; el verdadero sentido del régimen democrático exige el fortalecimiento del Ejecutivo [...] La vida actual es tan completa que, de un lado, muchos problemas de la vida social deben recibir una reglamentación administrativa y no legislativa,y, por otra parte, es el Ejecutivo quien juega predominante papel en el procedimiento legislativo. [...] Para redactar la inmortal Declaración de derechos, no se precisaba recurrir a los técnicos; pero para confeccionar una ley de seguros sociales sobre la protección a la maternidad o un código viario, se precisa constante mente la colaboración de técnicos de los que dispone con facilidad únicamente el Gobierno" [B. MiRKine-GuETzEVITCH, Modernas tendencias del Derecho constitucional (trad. de Sabino Alvarez Gendín), Reus, Madrid, 1934, pág. 202].

62 Estas preferencias políticas es la única explicación que encontramos a una actitud que llama la atención de LASSO: «La discusión en las Cortes fue tan breve, que más bien resplandece la falta de interés general por la reforma del Código; sólo ocupó una parte reducida de una sesión vespertina. Desde el banco azul, ni una sola intervención del Ministro. Las contestaciones a Osorio y Gallardo, sobre la pena de muerte, así como a Eduardo Ortega y Gasset y a Clara Campoamor, sobre las prisas, corrieron, como la defensa del dictamen, a cargo de Jiménez Asúa que se interesaba amorosamente del Proyecto" [Crónica de la codificación, cit, T. I, pág. 777]. Sobre el sistema de partidos, la composición de las Cortes y su funcionamiento en la II República, cfr. por toda la inmensa bibliografía, Joan Olıver Araujo, El sistema político de la Constitución española de 1931, Universitat de les Illes Balears, Palma, 1991, pág. 97 y ss. 


\section{EL FRANQUISMO}

Como en tantas otras cosas, la conculcación del principio de legalidad que hizo la Dictadura de Primo de Rivera pareció una levísima falta a la vista de lo que sucedió en el verano de 1936: la «justicia penal de guerra civil» que se inició con el bando de 28 de julio de 1936 creó un rosario de normas ajenas por completo a lo teorizado por Beccaria, Lardizábal y tantos otros: La ley (si se puede llamar así una norma no elaborada por ningún órgano representativo) de 5 de julio de 1938, que restableció la pena de muerte para los delitos de parricidio, asesinato y robo con homicidio; la Ley de responsabilidades políticas de 9 de febrero de 1939, que dio cobertura legal a la represión de la posguerra, la ley de represión de la masonería y el comunismo de 1 de marzo de 1940, la ley de seguridad del Estado de 29 de marzo de 1941, etc. Lo más benévolo que se puede decir de esta legislación es que «las necesidades del Nuevo Estado reclamaban una política de autodefensa [...] Para satisfacerlas se dieron leyes represivas con efectos retroactivos varias de ellas, caracterizadas por la severidad de sus sanciones y por estar encomendada su aplicación a tribunales especiales, formados algunos de ellos por generales, autoridades de Falange y algún Magistrado» ${ }^{63}$.

La progresiva institucionalización del régimen franquista ${ }^{64}$ supuso el abandono paulatino de sus rasgos más dictatoriales y una apariencia de Estado de Derecho (la «democracia orgánica») que tuvo repercusión en el ámbito del Derecho Penal: en 1944 se aborda la sustitución del Código de 1932 siguiendo aparentemente el tradicional sistema de la cobertura legal: la Ley de 19 de Julio de 1944 fija las bases y el Decreto de 23 de Diciembre de 1944 «aprueba y promulga el 'Código penal, texto refundido de 1944'». Pero el texto resultante, a pesar de que mantiene el principio de legalidad (art. 1 y 23) se encuentra muy lejos de un Código penal democrático: no ya sólo por su evidente origen, carente de legitimidad, sino por su contenido, repleto de delitos políticos ("la propaganda ilegal», "contra la Religión Católica», "contra la forma de Estado", asociaciones y manifestaciones ilícitas, etc.).

63 José ANTÓN ONECA, "El Derecho Penal de la postguerra» en VVAA, Problemas actuales de Derecho Penal y Procesal, Universidad de Salamanca, 1971, pág. 165.

64 Sobre las etapas del régimen franquista, cfr., por todos los autores, Gregorio CÁmARA VILLAR, «Analizar el franquismo: interpretaciones sobre su naturaleza», en VV.AA. Política y sociedad. Estudios en homenaje a Francisco Murillo Ferrol, CIS-CEC, Madrid, 1987, pág. 645-672. Sobre su «fraude constitucional» vid. Bartolomé ClAVERo, Evolución histórica..., cit, pág. 143 y ss. Sobre la elaboración del CP de 1944 y de sus posteriores reformas (hasta la de 1985), Juan Francisco LAsso GaITE, Crónica de la codificación, cit, T. I, pág. 796-920. 
En la labor cosmética de parecerse a un Estado liberal el franquismo se daría una Leyes Fundamentales, en una de las cuales (la del Fuero de los Españoles de 17 de julio de 1945) se recogía el principio de legalidad: «Nadie podrá ser condenado sino en virtud de Ley anterior al delito, mediante sentencia del Tribunal competente y previa audiencia y defensa del interesado" (art. 19). También en dos ocasiones posteriores modernizaría el franquismo el Código: en 1963 se aprobó un «texto revisado" y en 1973 un «texto refundido». En las dos ocasiones se siguió la misma técnica de una ley de bases (79/1961, de 23 de diciembre y 44/1971, de 15 de noviembre) y posterior decreto con el texto articulado (de 28 de marzo de 1963 y 3096/1973, de 14 de septiembre). Sin duda, ambas fueron en la línea de equiparar el Derecho penal español con el del resto del continente, pero debajo de su mayor o menor técnica -que es cuestión que discute la doctrina, y ahora no nos interesa- siempre mantuvo inalterados dos rasgos diferenciadores: a) no era producto de una voluntad general, no lo habían elaborado los representantes libremente elegidos por los ciudadanos: b) $-\mathrm{y}$ consecuencia directa de lo anterior- mantenía unos delitos de opinión ajenos a la democracia.

Por eso, el principio nullum crimen nulla poena sine lege podia mantenerse en el artículo 23 del Código penal y servir para impedir la interpretación analógica y cualquier otra técnica interpretativa in malam partem, como señalaba la jurisprudencia del Tribunal Supremo (SS 2-3-1946 y 5-12-1959, por ejemplo); pero, a poco que se levante la vista y se mire más allá de su articulado, se deberá señalar que el Código penal en sí mismo negaba los postulados esenciales del principio de legalidad: si éste - siguiendo a Beccaria- implica que sólo el legislador, "que representa a toda la sociedad unida por el contrato social”, puede establecer los delitos y las penas con la finalidad de punir a los que ataquen «el vínculo necesario para tener unidos los intereses particulares», entonces la concentración del poder legislativo en unas pocas manos (en último término sólo en dos: en las de Franco, que incluso jurídicamente mantuvo siempre las competencias de las Leyes de prerrogativa de 1938 y 1939) y la punición de las conductas contrarias a los intereses de los que así gobernaban (los delitos políticos y de opinión) conculcaban el principio de legalidad, rectamente entendido ${ }^{65}$.

65 De aquí se colige que una de las primera leyes que se aprobaron para recomponer el pacto social y acabar con la dictadura fuera la Ley 23/1976, de 19 de julio, sobre modificación de determinados artículos del Código Penal relativos a los derechos de reunión, asociación, expresión de las ideas y libertad de trabajo. Sobre la transición cfr. Ramón CotaRELo (comp.), Transición politica y consolidación democrática. España (1975-1986), CIS, Madrid, 1992, y la bibliografía allí citada. 


\section{RECAPITULACIÓN}

El principio de legalidad penal no tiene su origen hasta la llustración porque solo entonces se concibe como monopolio del poder legislativo -representante de los ciudadanos- para establecer los delitos y las penas estrictamente necesarias para la conservación de la sociedad. Los precedentes habitualmente citados (las Cartas Magnas inglesa y leonesa, los Fueros de Aragón) y otros que hemos espigado en la Historia (Petición de los procuradores castellanos de 1598) no son, hablando estrictamente, los orígenes ya que se produjeron en un mundo completamente diferente, ajeno al Estado de Derecho y la división de poderes. En el plano jurídico hay que esperar hasta la Declaración de Delawere de 1776 para verlo expresado. Su formulación clásica es el artículo 8 de la Declaración de Derechos del Hombre y el ciudadano de 1789. Igualmente sucede en el plano teórico: cualquier alegación a favor de Bacon, Hobbes, Alfonso de Castro, Grocio, etc., como creadores del principio de legalidad fuerza las categorias (y levanta la consecuente polémica) porque no hay un planteamiento claro y expreso del problema hasta el Siglo de las Luces. MONTESQUIEU desbrozó el camino que recorrería luego brillantemente CESARE BECCARIA.

Todas las Constituciones históricas españolas recogen el principio de legalidad penal. La única que no lo hace expresamente es la de Cádiz, pero -en contra de cierto sector doctrinal- creemos que se puede deducir de su interpretación sistemática; incluso se puede afirmar que la Constitución de 1812 es la más rigurosa porque al basarse en la estricta división de poderes crea una reserva de Parlamento para la aprobación del Código penal, tal y como se demuestra porque sólo el Código de 1822 se elaboró y aprobó íntegramente por las Cortes. Más todavía, en cuanto concibe el ius puniendi como un todo indivisible que se atribuye exclusivamente a los tribunales, desconoce la potestad sancionadora de la Administración.

En su conjunto, y sólo con pequeñas diferencias de detalle, las Constituciones históricas españolas consagran el principio de legalidad con sus cuatro garantías clásicas, guardando silencio sobre el principio de proporcionalidad y sobre la potestad sancionadora de la Administración, que luego le fue reconocida en textos subconstitucionales. Ahora bien, y esto es algo que no suele señalar la doctrina, cuando se redactaron los distintos Códigos no se mantuvo el monopolio absoluto de las Cortes en su elaboración, sino que se hizo unas veces según la técnica de la autorización (las Cortes autorizaban la publicación de un proyecto que previamente le había presentado el Gobierno) y otras con la de la delegación (las Cortes aprobaban una ley 
de bases que posteriormente el Gobierno desarrollaba en un Decreto). La única Constitución que impide ambas técnicas y establece una auténtica reserva de Parlamento es la que más críticas doctrinales ha recibido: la de 1978. Pero esa es otra historia, que no podemos contar ahora. 